\title{
The activity of $\sigma^{32}$ is reduced under conditions of excess heat shock protein production in Escherichia coli
}

\author{
David B. Straus, William A. Walter, and Carol A. Gross \\ Department of Bacteriology, University of Wisconsin, Madison, Wisconsin 53706 USA
}

\begin{abstract}
The expression of heat shock genes in Escherichia coli is controlled by the action of an alternate $\sigma$-factor of RNA polymerase, $\sigma^{32}$, which directs core RNA polymerase to recognize the promoters for heat shock genes. After a shift from $30^{\circ} \mathrm{C}$ to $42^{\circ} \mathrm{C}$, both the level of $\sigma^{32}$ and transcription initiation at heat shock promoters transiently increase, indicating that heat shock gene expression is regulated by changes in the concentration of $\sigma^{32}$. Here, we report that heat shock gene expression is regulated by changes in the activity of $\sigma^{32}$ under some conditions. Our results show that the transient repression of heat shock protein synthesis, which follows a shift down from $42^{\circ} \mathrm{C}$ to $30^{\circ} \mathrm{C}$, occurs as a result of decreased transcription initiation at heat shock promoters, but this repression is accompanied by only a small decrease in the level of $\sigma^{32}$. In addition, the induction of heat shock proteins following overproduction of $\sigma^{32}$ from a multicopy plasmid is only transient, despite the fact that the level of $\sigma^{32}$ remains elevated. Constitutive overproduction of $\sigma^{32}$ also fails to cause a proportionate increase in heat shock gene transcription. These three examples suggest that the activity of $\sigma^{32}$ is reduced under conditions of excess heat shock gene expression.
\end{abstract}

[Key Words: Heat shock; $\sigma^{32}$; E. coli]

Received July 21, 1989; revised version accepted September 27, 1989.

When Escherichia coli cells are abruptly shifted from low to high growth temperature, there is a transient induction in the synthesis of $\sim 20$ proteins, the heat shock proteins (for review, see Neidhardt and VanBogelen 1987). This response has been observed in almost all organisms, including members of the archebacterial, eubacterial, and eukaryotic kingdoms. The primary structure of at least some of the heat shock proteins has been conserved between organisms as divergent as bacteria and man, suggesting that the function as well as the regulation of heat shock proteins may be similar among different species.

Some of the regulatory events leading to heat shock response in $E$. coli have been elucidated. An alternate $\sigma$-factor of RNA polymerase, $\sigma^{32}$, the product of the $r p o H(h t p R)$ gene, directs core RNA polymerase to recognize the promoters for heat shock genes (Grossman et al. 1984; Cowing et al. 1985; Bloom et al. 1986). Changes in the concentration of this alternate $\sigma$-factor are responsible for regulating transcription of heat shock genes during heat shock. Following temperature upshift, the intracellular level of $\sigma^{32}$ increases transiently, leading to a burst of heat shock gene transcription (Lesley et al. 1987; Skelly et al. 1987; Straus et al. 1987). Artificial overproduction of $\sigma^{32}$ without a temperature shift also results in the induction of heat shock proteins (Grossman et al. 1987). These results indicate that heat shock gene expression is controlled by the concentration of $\sigma^{32}$.
When E. coli cells are subjected to a rapid shift from high to low temperature within the normal growth range, a response reciprocal to heat shock is observed: Immediately following temperature downshift, heat shock protein synthesis is repressed (Lemaux et al. 1978; Gross et al. 1984). Although the cause of this drop in synthesis has not been investigated previously, it appeared likely that regulation of heat shock gene expression following temperature downshift would occur by the reverse of the mechanism utilized during heat shock induction. However, this is not the case. We show that initiation of heat shock gene transcription is repressed following temperature downshift by a mechanism independent of the concentration of $\sigma^{32}$. Other conditions that result in the synthesis of excess heat shock proteins reduce the activity of RNA polymerase containing $\sigma^{32}$ at the promoters of heat shock genes.

\section{Results \\ Regulation of heat shock gene expression upon temperature downshift}

When E. coli cells are shifted from $42^{\circ} \mathrm{C}$ to $30^{\circ} \mathrm{C}$, the synthesis of heat shock proteins is repressed. Figure $1 \mathrm{~A}$ shows an autoradiograph from an SDS-polyacrylamide gel of extracts from cells that had been pulse-labeled with $\left.{ }^{35} \mathrm{~S}\right]$ methionine either at $42^{\circ} \mathrm{C}$ or after a shift down to $30^{\circ} \mathrm{C}$. The DnaK and GroEL heat shock proteins (indi- 

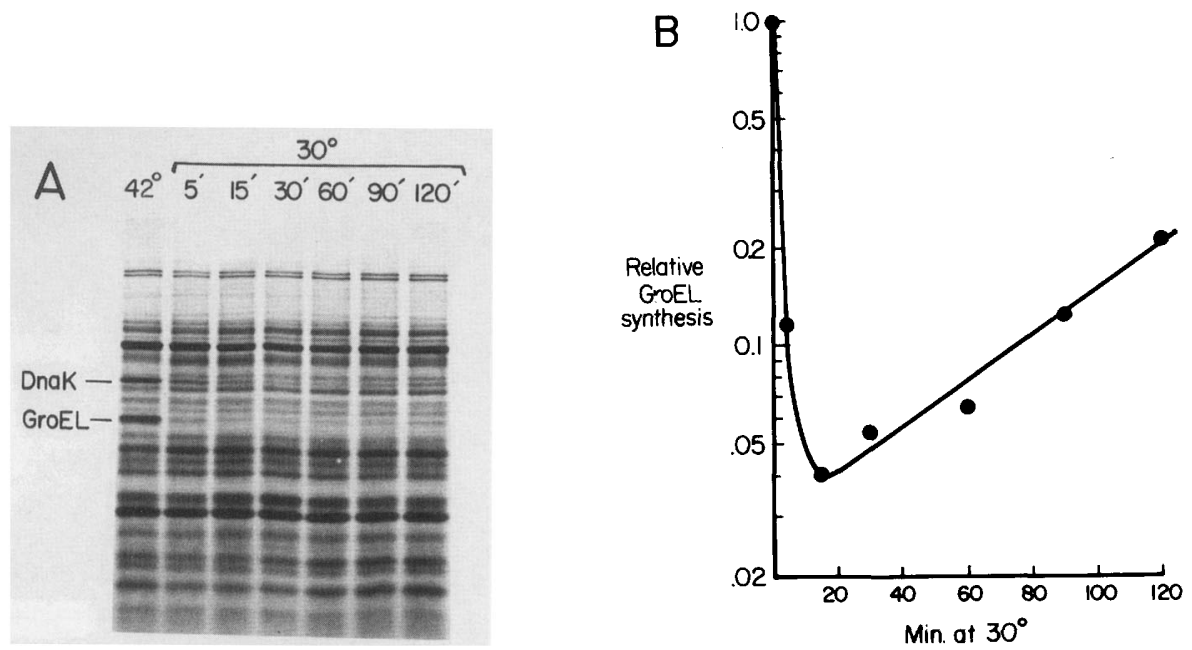

Figure 1. Repression of heat shock protein synthesis following shift from $42^{\circ} \mathrm{C}$ to $30^{\circ} \mathrm{C}$. $(A)$ Equal counts per minute from extracts of cells pulse-labeled with $\left[{ }^{35} \mathrm{~S} \mid\right.$ methionine at $42^{\circ} \mathrm{C}$, or at the indicated times after shift to $30^{\circ} \mathrm{C}$, were analyzed on an SDS-polyacrylamide gel. The positions of DnaK and GroEL heat shock proteins are indicated. $(B)$ Relative synthesis of GroEL after temperature downshift was examined quantitatively, as described in Materials and methods, by immunoprecipitation from extracts of cells that had been pulse-labeled with $\left[{ }^{35} \mathrm{~S}\right]$ methionine. GroEL synthesis is expressed as a fraction of total protein synthesis, normalized to its rate of synthesis at $42^{\circ} \mathrm{C}$.

cated in Fig. 1A) show a dramatic drop in synthesis after temperature downshift. A number of other proteins are mildly induced by the temperature downshift. Immunoprecipitation of GroEL from extracts of cells that had been similarly pulse-labeled indicated that its synthesis rate decreased rapidly so that by $15 \mathrm{~min}$ after shift to low temperature, GroEL synthesis was only $5 \%$ of its initial rate (Fig. 1B). This repression is transient but requires more than two generations to reach the $30^{\circ} \mathrm{C}$ steadystate rate of synthesis.

We used operon fusions between several heat shock promoters and the galactokinase gene to determine whether the drop in heat shock protein synthesis was the result of a change in transcription initiation. Following temperature downshift, synthesis of galactokinase directed by the groE, dnaKPl, and $h t p G$ heat shock promoters dropped $\sim 20$-fold, whereas synthesis of galactokinase directed by a non-heat-shock promoter, gal, declined only slightly (Table 1). S1 nuclease analysis of transcripts from the groESL operon also indicated that the number of transcripts from the groE heat shock promoter dropped $\sim 20$-fold after a shift from high to low temperature (data not shown). These findings indicate that, like the induction of heat shock protein synthesis following temperature upshift, repression of heat shock protein synthesis during downshift is due to changes in initiation of transcription at heat shock promoters.

Heat shock promoter-GalK fusions that had deletions of DNA sequence either $5^{\prime}$ or $3^{\prime}$ of the conserved promoter region were used to determine what sequences were required for regulation of promoter activity following temperature downshift. A fusion of dnaKP2 to galK deletes all $d n a K$ sequences downstream of the first nucleotide of the dnaK transcript (Cowing et al. 1985). Analysis of transcripts from this promoter by S1 map- ping showed that promoter activity is repressed after shift from $42^{\circ} \mathrm{C}$ to $30^{\circ} \mathrm{C}$ (Fig. 2, lanes 5, 6). In addition, a deletion that removes all of the groE sequences upstream of the conserved promoter sequences in the -35 region (J. Mecsas, D. Cowing, and C. Gross, unpubl.), shows the same regulation as the intact promoter (Fig. 2, lanes $1-4)$. The shorter, unregulated transcript present in both the intact and deleted groE promoter fusion is the product of a promoter recognized by RNA polymerase containing $\sigma^{70}$ (Zhou et al. 1988). These results suggest that only the immediate promoter region is required for the repression of transcription initiation at heat shock promoters after temperature downshift.

Heat shock promoters are recognized solely by RNA polymerase containing $\sigma^{32}$ (Cowing et al. 1985; Fujita et al. 1987; Zhou et al. 1988). We measured the level of $\sigma^{32}$ during a temperature downshift to see if a decrease in its concentration could explain the repression of heat shock

Table 1. Expression of heat shock promoter fusions to galK following temperature downshift

\begin{tabular}{llcc}
\hline & $42^{\circ} \mathrm{C}$ & $30^{\circ} \mathrm{C}$ & $30^{\circ} / 42^{\circ} \mathrm{C}$ \\
\hline Pgal & 1 & 0.89 & 0.89 \\
PgroE & 0.76 & 0.04 & 0.05 \\
dnaKP1 & 0.39 & 0.02 & 0.05 \\
PhtpG & 0.37 & 0.02 & 0.05 \\
\hline
\end{tabular}

The relative synthesis of galactokinase directed by the gal, groE, dnaKPl, and $h t p G$ promoters at $42^{\circ} \mathrm{C}$, and $20 \mathrm{~min}$ after shift down to $30^{\circ} \mathrm{C}$, was determined by immunoprecipitation of galactokinase from cells pulse-labeled with $\left.{ }^{35} \mathrm{~S}\right]$ methionine as described in Materials and methods. The values are the average of duplicate samples, normalized to expression of GalK directed by the gal promoter at $42^{\circ} \mathrm{C}$. 


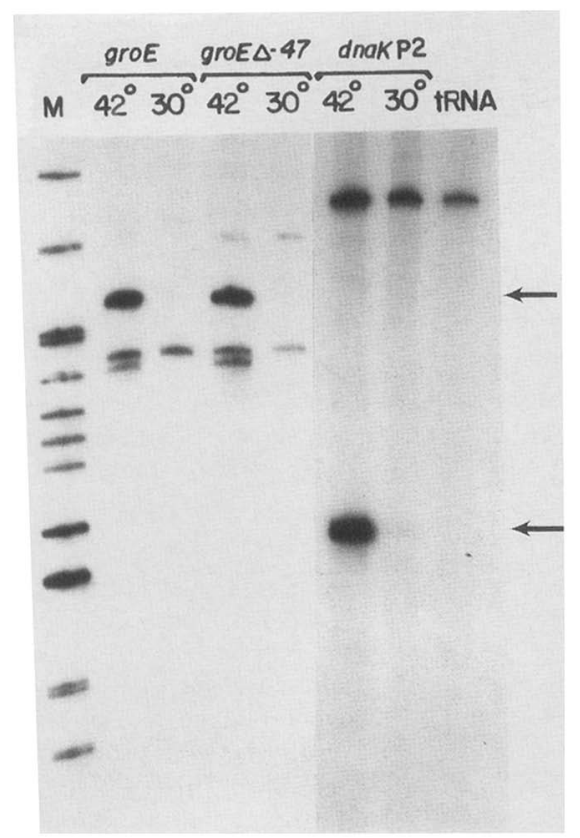

Figure 2. S1 mapping of transcripts made from heat shock promoter fusions to galK at $42^{\circ} \mathrm{C}$ and after shift to $30^{\circ} \mathrm{C}$. RNA was prepared from strains carrying pDC440 (groE-galK) (lanes 1 and 2), pDC441 $\Delta-47$ (groEs-47-galK) (lanes 2 and 3), or pDC403 (dnaKP2-galK) (lanes 5 and 6). Samples were taken from cultures growing at $42^{\circ} \mathrm{C}$ or at $20 \mathrm{~min}$ after shift to $30^{\circ} \mathrm{C}$. Sl mapping was carried out as described in Materials and methods using DNA probes end-labeled at restriction sites homologous only to plasmid-derived transcript. Transcripts originating from the groE heat shock promoter on pDC440 and pDC441 $\Delta-47$ produce a protected DNA fragment of 250 nucleotides. Transcripts from the $d n a K \mathrm{P} 2$ promoter of $\mathrm{pDC} 403$ produce a protected DNA fragment of 150 nucleotides. Lane 7 is the dnaKP2 probe hybridized with tRNA alone. The 335-nucleotide band in lanes $5-7$ is undigested probe.

gene expression under these conditions. Western blot analysis showed that the level of $\sigma^{32}$ decreased only $\sim 2$ fold during the first $10 \mathrm{~min}$ after shift from $42^{\circ} \mathrm{C}$ to $30^{\circ} \mathrm{C}$ (Fig. 3), although heat shock protein synthesis dropped $\sim 20$-fold during the same time period (Fig. 1). The level of $\sigma^{32}$ continues its slow decline for $60 \mathrm{~min}$ after temperature downshift before reaching its $30^{\circ} \mathrm{C}$ steady-state level $\sim 4$-fold lower than the $42^{\circ} \mathrm{C}$ level. This result indicates that the reduction in transcription initiation at heat shock promoters following a temperature downshift cannot be accounted for by a drop in the concentration of $\sigma^{32}$.

\section{Regulation of heat shock gene expression following overproduction of $\boldsymbol{\sigma}^{32}$}

Following a temperature downshift, heat shock proteins are initially present at a concentration optimal for growth at high temperature rather than low temperature. The reduced expression of heat shock genes following a shift from $42^{\circ} \mathrm{C}$ to $30^{\circ} \mathrm{C}$ may be a response to excess heat shock proteins. If this hypothesis is correct, then other conditions that result in the presence of excess heat shock proteins may also lead to the repression of heat shock gene transcription without a change in the level of $\sigma^{32}$. Excess heat shock proteins can be generated without a temperature shift by artificially overproducing $\sigma^{32}$ (Grossman et al. 1987). The $\sigma^{32}$ overproducer plasmid pDS1 carries the rpoH gene under control of the IPTGinducible tac promoter. When $\sigma^{32}$ was overproduced at $30^{\circ} \mathrm{C}$ in strains with pDS1 by the addition of $100 \mu \mathrm{M}$ IPTG, the level of $\sigma^{32}$ increased and remained elevated over $60 \mathrm{~min}$ (Fig. 4A). However, synthesis of the DnaK and GroEL heat shock proteins was only transiently induced. Immunoprecipitation of the two heat shock proteins from extracts of cells that had been pulse-labeled with $\left.{ }^{35} \mathrm{~S}\right]$ methionine during the overproduction of $\sigma^{32}$ showed that their synthesis peaked at $\sim 10 \mathrm{~min}$ after the addition of IPTG and then declined (Fig. 4B). When strains carrying pDS1 are fully induced with $1 \mathrm{mM}$ IPTG, the induction of heat shock proteins is still transient, but the decline in their synthesis rate is more gradual than observed with a partial induction of $\sigma^{32}$ (data not shown). We used the fusion of the groE heat shock promoter to galK to determine whether the shutoff of heat shock gene expression at later times after overproduction of $\sigma^{32}$ was the result of regulating transcription from heat shock promoters. Like the synthesis of DnaK and GroEL, the synthesis of galactokinase directed by the groE heat shock promoter is only transiently induced following overproduction of $\sigma^{32}$ (Fig. 4C). This regulation of heat shock gene expression, like the regulation after a temperature downshift, is the result of a decrease

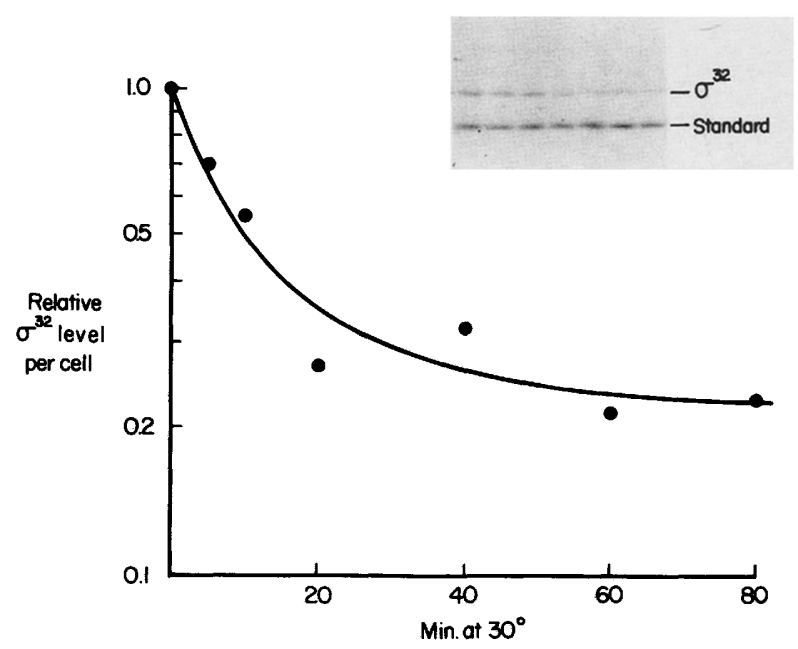

Figure 3. $\sigma^{32}$ level following shift from $42^{\circ} \mathrm{C}$ to $30^{\circ} \mathrm{C}$. The level of $\sigma^{32}$ in wild-type strain CAG1 1064 growing at $42^{\circ} \mathrm{C}(0 \mathrm{~min})$, or at $5,10,20,40,60$, and $80 \mathrm{~min}$ after shift to $30^{\circ} \mathrm{C}$ was determined by Western blotting, as described in Materials and methods. The insert shows a $\sigma^{32}$ blot of samples representing equal cell densities taken during temperature downshift, and the graph is a plot of values obtained by scanning an equivalent blot. A mutant form of $\sigma^{32}$, which migrates faster than the wild-type protein in SDS-polyacrylamide gels, was included in each sample to correct any losses during the analysis. 


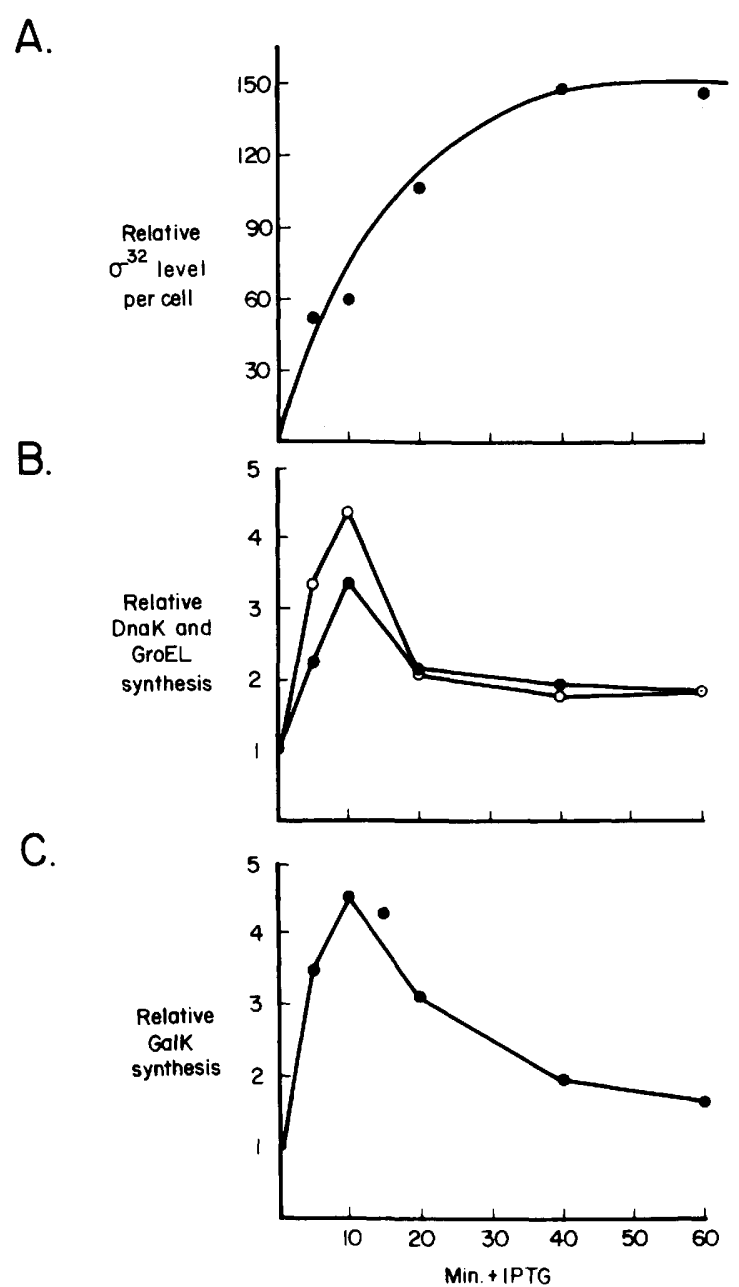

Figure 4. Heat shock gene expression following overproduction of $\sigma^{32}$ at $30^{\circ} \mathrm{C}$. $(A)$ Western blot analysis of $\sigma^{32}$ level following induction of Ptac-rpoH. (B) Relative synthesis of the DnaK $(O)$ and GroEL $(O)$ heat shock proteins following induction of $\sigma^{32}$ (C) Synthesis of GalK directed by the groE heat shock promoter following the induction of $\sigma^{32}$. Strain CSH26 $\mathrm{F}^{\prime} l a c I^{q}$ carrying $\mathrm{pDS} 1(A$ and $B)$ and $\mathrm{pDC} 440(C)$ was grown at $30^{\circ} \mathrm{C}$, and $\sigma^{32}$ synthesis was induced at $0 \mathrm{~min}$ by the addition of $100 \mu \mathrm{M}$ IPTG. The level of $\sigma^{32}$ present in aliquots of cell culture before and after IPTG addition was determined by Western blotting, as described in Materials and methods. The values were corrected for cell growth during the experiment and normalized to the preinduction level of $\sigma^{32}$. The synthesis of DnaK, GroEL, and GalK was determined by immunoprecipitation from extracts of cells pulse-labeled with $\left[{ }^{35} \mathrm{~S}\right]$ methionine before and after the induction of $\sigma^{32}$. The synthesis rates of the individual proteins were determined relative to total protein synthesis and then normalized to the preinduction rates.

in transcription initiation at heat shock promoters by a mechanism independent of $\sigma^{32}$ concentration.

The adaptive response to $\sigma^{32}$ overproduction can also be inferred from observations of strains that constitutively overproduce $\sigma^{32}$. Table 2 compares data on the level of $\sigma^{32}$ and the synthesis of mRNA from the dnaKI heat shock operon in wild-type cells and two strains that have increased amounts of $\sigma^{32}$. Western blot analysis showed that a strain carrying plasmid pKP11, which includes the $r p o H$ gene and its promoter region, has 15-20 times the level of $\sigma^{32}$ present in the wild-type strain. A strain carrying the grpE280 allele also has 15-20 times the wild-type level of $\sigma^{32}$, because this strain is defective in the degradation of the $\sigma$-factor (D. Straus, W. Walter, and C.A. Gross, in prep.). Despite the enhanced levels of $\sigma^{32}$ in these strains, the synthesis of $d n a K J$ mRNA, determined by pulse-labeling with $\left[{ }^{3} \mathrm{H}\right]$ uridine and filter hybridization, is increased only slightly compared to the wild-type control (Table 2, column 2). Measurements of heat shock protein synthesis in these strains are consistent with the measurements of $d n a K J$ mRNA synthesis (data not shown). The disparity between the amount of $\sigma^{32}$ and the synthesis of heat shock gene mRNA suggests that the excess $\sigma^{32}$ present in these strains is unable to function.

\section{Post-translational loss of $\sigma^{32}$ function}

If newly synthesized $\sigma^{32}$, or RNA polymerase containing $\sigma^{32}$, goes through a process of inactivation in strains containing constitutively high levels of $\sigma$-factor, then $\sigma^{32}$ function should be unstable. In wild-type strains $\sigma^{32}$ function is normally unstable because the $\sigma$-factor is rapidly degraded (Straus et al. 1987). However, the high constitutive level of $\sigma^{32}$ in the grpE mutant is the result of a defect in $\sigma^{32}$ degradation, making it feasible to determine whether there is a difference between the functional half-life and the chemical half-life of $\sigma^{32}$ in this strain. The functional half-life of $\sigma^{32}$ was determined in the wild-type and grpE mutant by examining the ability of the strains to synthesize $d n a K J$ mRNA at various times after further production of $\sigma^{32}$ was inhibited by the addition of chloramphenicol. As expected, the functional half-life of $\sigma^{32}$ in the wild-type strain, $t 1 / 2=1-2$ min, reflects its chemical half-life (Fig. 5). In contrast, the $\operatorname{grp} E$ mutant exhibited a functional half-life of $\sigma^{32}$ $t 1 / 2=1-2 \mathrm{~min})$, which was much shorter than the chemical half-life of $\sigma^{32}$ in this strain $(t 1 / 2=10-20 \mathrm{~min})$. This result suggests that, at least in the grpE mutant, the decrease in apparent activity of $\sigma^{32}$, or RNA polymerase containing $\sigma^{32}$, is the result of an inactivation process that occurs soon after synthesis.

Table 2. Comparison of $\sigma^{32}$ level and dnaKJ $m R N A$ synthesis at $30^{\circ} \mathrm{C}$ in wild-type, multicopy $\mathrm{rpoH}$, and grpE280 strains

\begin{tabular}{llc}
\hline & $\sigma^{32}$ level & $\begin{array}{l}\text { dnaKJ } \\
\text { mRNA synthesis }\end{array}$ \\
\hline Wild type & 1 & 1 \\
pKP11 & $15-20$ & 1.8 \\
grpE280 & $15-20$ & 2.6 \\
\hline
\end{tabular}

The level of $\sigma^{32}$ per cell in cultures of CAG11064, with pKP11 or grpE280, was determined by Western blotting and the values normalized to the wild-type level. The synthesis of dnaKJ mRNA was determined by pulse-labeling cell cultures with $\left[{ }^{3} \mathrm{H}\right]$ uridine and hybridizing the RNA to denatured $\lambda d$ naKJ DNA bound to nitrocellulose filters. The synthesis of dnaKJ mRNA in each strain, determined as a fraction of total RNA synthesis, was normalized to the wild-type rate of synthesis. 


\section{Discussion}

The cellular content of heat shock proteins is closely related to the growth temperature (Herendeen et al. 1979). Elaborate mechanisms operate to rapidly adjust the level of heat shock proteins following changes in growth temperature, which presumably reflect the essential role of heat shock proteins in growth at high temperature (Neidhardt and Van Bogelen 1981; Yamamori and Yura 1982) and possibly a detrimental function of heat shock proteins when overexpressed at low temperature (Bahl et al. 1987). Previous work has indicated that regulation of heat shock expression following a temperature upshift, or after exposure to a number of other stimuli, is the result of changes in heat shock gene transcription, controlled by the concentration of an alternate RNA polymerase $\sigma$-factor, $\sigma^{32}$ (Bahl et al. 1987; Straus et al. 1987). Our results indicate that immediately following temperature downshift, or under other conditions of apparent
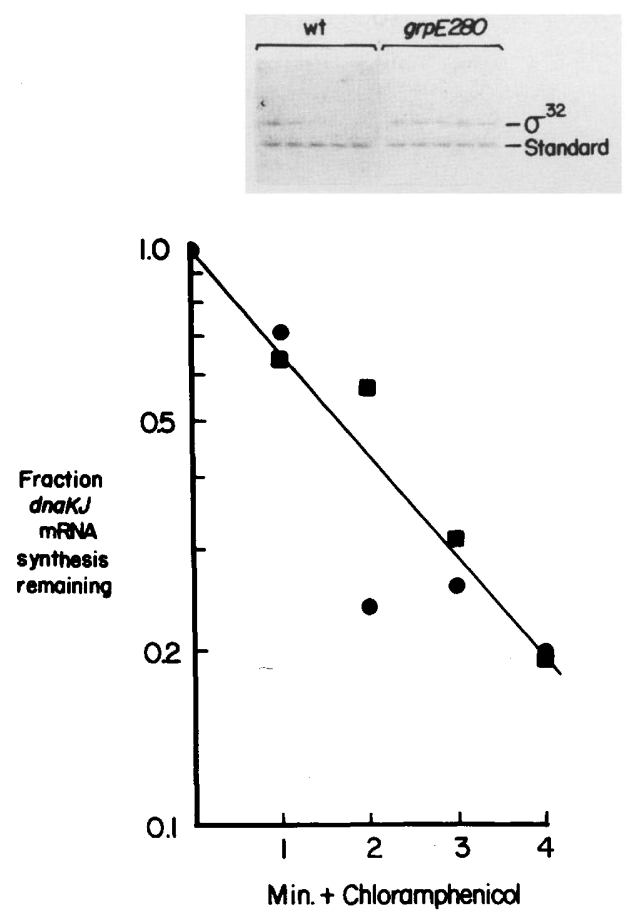

Figure 5. Stability of $d n a K J$ mRNA synthesis following inhibition of protein synthesis in wild-type and grpE280 strains. Strain CAG11064 (wild type) (O), and CAGl1066 (grpE280 (D) were grown at $30^{\circ} \mathrm{C}$, and chloramphenicol was added $(100$ $\mu \mathrm{g} / \mathrm{ml}$ ) at $0 \mathrm{~min}$ to inhibit protein synthesis. Aliquots of cell culture were labeled with $\left[{ }^{3} \mathrm{H}\right]$ uridine, either before or at 0.5 , $1.5,2.5$, and $3.5 \mathrm{~min}$ after the addition of chloramphenicol. RNA was prepared and hybridized to denatured $\lambda d n a K I$ DNA bound to nitrocellulose filters, as described in Materials and methods. The synthesis of $d n a K J$ mRNA in each strain, determined as a fraction of total RNA synthesis, was normalized to the rate of synthesis before addition of chloramphenicol and plotted at the mid-point of the labeling periods. The insert shows a $\sigma^{32}$ Western blot of samples from the wild-type and grpE280 strains taken before and at 1,2,3, and 4 min after addition of chloramphenicol. Samples from the grpE280 strain were diluted 20 -fold relative to samples from the wild-type strain. excess heat protein synthesis, heat shock gene expression is repressed at the level of transcription. Unlike the case of the heat shock response, this regulation is independent of the concentration of $\sigma^{32}$.

We have examined heat shock gene expression in three situations where there is an apparent excess of heat shock proteins. When cells are shifted from $42^{\circ} \mathrm{C}$ to $30^{\circ} \mathrm{C}$, the level of heat shock proteins is initially $\sim 2$-fold greater than normally found at the low temperature (Herendeen et al. 1979). Following temperature downshift, expression of heat shock genes is rapidly repressed resulting in a drop of $>20$-fold in the rate of heat shock protein synthesis by $15 \mathrm{~min}$ after shift to $30^{\circ} \mathrm{C}$. During the same time period, the level of $\sigma^{32}$ dropped only 2- to 3 -fold. Similarly, when the cellular content of heat shock proteins was increased by overexpressing $\sigma^{32}$ from an inducible promoter, heat shock protein synthesis was repressed after the initial induction, despite the fact that the level of $\sigma^{32}$ remained elevated. Examination of galactokinase synthesis controlled by heat shock promoters showed that the reduced expression of heat shock genes following temperature downshift, or after overproduction of $\sigma^{32}$, was the result of decreased transcription initiation at heat shock promoters. A similar conclusion was recently reached by Tauro et al. (1989). The regulatory site is limited to the immediate promoter region because deletions upstream or downstream of heat shock promoters did not affect the regulation. Uncoupling of heat shock gene transcription from the concentration of $\sigma^{32}$ was also observed in strains where $\sigma^{32}$ overproduction is constitutive. Strains with a plasmid carrying the $r p o H$ gene, or with the grpE280 mutation, had 15 - to 20 -fold more $\sigma^{32}$ than wild-type strains, but mRNA from the dnaKJ heat shock operon was synthesized at rates only slightly higher than wild type. Presumably all three cases-temperature downshift and transient and constitutive $\sigma^{32}$ overproduction-share a common mechanism for the regulation of transcription initiation at heat shock genes, which is independent of the concentration of $\sigma^{32}$.

These observations do not alter the conclusions from previous work indicating that heat shock gene expression is normally limited by the concentration of $\sigma^{32}$. Artificial overproduction of $\sigma^{32}$ results in the induction of heat shock proteins (Grossman et al. 1987), and the transient induction of heat shock gene expression following temperature upshift and exposure to ethanol can be explained by changes in the concentration of $\sigma^{32}$ (Straus et al. 1987). Because of these findings, it was surprising to find conditions where changes in the expression of heat shock genes were not accompanied by changes in the level of $\sigma^{32}$. However, the mechanism for regulating the concentration of $\sigma^{32}$, which allows for a rapid increase in its concentration during heat shock and following other stresses may prohibit a rapid decrease in $\sigma^{32}$ during a temperature downshift. Because $\sigma^{32}$ is very unstable, a rapid decrease in its concentration could be brought about by simply shutting off synthesis of the alternate $\sigma$-factor. Previous work, however, suggests that the synthesis of $\sigma^{32}$ is already repressed during steady-state 
growth by a mechanism controlling translation of $r p o H$ mRNA and that heat shock causes a transient derepression of $\sigma^{32}$ synthesis (Straus et al. 1987). Following a temperature downshift, translation of $r p o H$ mRNA may already be as repressed as the mechanism permits, necessitating another means to reduce the expression of heat shock genes.

There are a number of mechanisms that could explain the mechanism of transcription initiation at heat shock promoters following temperature downshift and at later times after overproduction of $\sigma^{32}$. Even though the regulation is independent of $\sigma^{32}$ concentration, it could involve control of the concentration or specific activity of RNA polymerase containing $\sigma^{32}\left(E \sigma^{32}\right)$. Regulation of $E \sigma^{32}$ formation, or specific activity, could be brought about by modification of core RNA polymerase, or $\sigma^{32}$, or noncovalent interaction of core, or $\sigma^{32}$, with other proteins. Alternatively, a repressor molecule might bind to conserved sequences at heat shock promoters under the proper conditions and block transcription initiation.

The rapid loss of $\sigma^{32}$ function following inhibition of protein synthesis in the grpE280 mutant is most consistent with the idea that $\mathrm{E}^{32}$ formation, or activity, is inhibited in strains with high constitutive levels of $\sigma^{32}$. If a repressor molecule were responsible for controlling heat shock gene expression under these conditions, then $\sigma^{32}$ function would be stable, unless the addition of chloramphenicol generated a corepressor. The reduction of heat shock gene expression following inhibition of protein synthesis in the grpE280 mutant suggests that newly synthesized $\sigma^{32}$ and $E \sigma^{32}$ are functional, but one or both undergo a process of inactivation.

We have been unable to duplicate the regulation of heat shock gene transcription in vitro. Preliminary experiments have demonstrated that the $\mathrm{E}^{32}$ activity present in lysates of cells overproducing $\sigma^{32}$ is consistent with the level of $\sigma^{32}$ in the cell rather than the apparent activity of $\mathrm{E}^{32}$ in vivo. RNA polymerase was rapidly purified by polyethylene glycol (PEG) precipitation of DNA from cell lysates and salt elution of polymerase from the DNA (Gross et al. 1976). E $\sigma^{32}$ activity, assessed by in vitro transcription from the dnaKP2 heat shock promoter, was much higher in lysates from strains carrying the $r p o H$ plasmid than in lysates from the wild-type strain. In contrast, the in vivo rate of heat shock gene transcription in the two strains is essentially equivalent. Thus, if the formation or specific activity of $\mathrm{E}^{32}$ is altered under conditions where $\sigma^{32}$ is overproduced, then the alteration is unstable in vitro. It is tempting to speculate that the formation or activity of $E \sigma^{32}$ is inhibited in vivo by noncovalent association with excess heat shock proteins, a number of which have been shown to influence protein-protein interactions (Liberek et al. 1988; Dodson et al. 1989; Goloubinoff et al. 1989) and this interaction is sufficiently weak so that it is not maintained upon dilution in vitro. Preliminary experiments indicating that mutations in the $d n a K, d n a I$, and grpE genes result in defects in the regulation of heat shock gene expression on temperature downshift provide support for this idea (D. Straus, N. Kusukawa, and T. Yura, unpubl.).

\section{Materials and methods}

Strains and plasmids

Strains for most experiments were derived from C600 (thi, thr, leu, supE, lacY, tonA). CAG11064 is C600 galK, lacZX90/ $\mathrm{F}^{\prime} l a c I^{q}$, lacZ:: Tn5, CAG11066 is C600 grpE280, galK, lacZX90/F'lacIq, lacZ :: TN5. Plasmids pDC440, pDC401, pDC403, and pDC404 fuse the groE, dnaKP1, dnaKP2, and $h t p G$ heat shock promoters to the galK gene, as described in Cowing et al. (1985). pKG1900 fuses the gal promoter to galK (McKenney et al. 1981). Plasmid pDC441 $\Delta-47$ is the groE promoter fused to galK in pKO500, lacking all groE sequences upstream of the -47 position of the promoter. The plasmid was made by BAL-31 treatment of pDC441, and the deletion end point was determined by dideoxy sequencing (J. Mecsas, D. Cowing, and C. Gross, data not shown). The galK fusion plasmids were carried in strain C600 galK. Plasmid pKP11 (Paek and Walker 1986), containing the rpoH region of the chro-

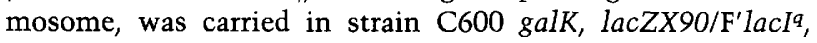
lacZ :: Tn5. The $r p o H$ gene from pKP11 is functional because it can complement $r p o H$ mutations even when it is present in single copy (Zhou et al. 1988). Plasmid pDS1, described in Bahl et al. (1987), fuses the IPTG-inducible tac promoter to $r p o H$ in plasmid pACYC184. Strain CSH26 (ara, Dlac-pro, thi), containing $\mathrm{F}^{\prime} l a c^{q}$, lacZ :: Tn5, was used for experiments involving the overproduction of $\sigma^{32}$.

\section{Protein synthesis}

The synthesis of E. coli proteins was examined by pulse-labeling with $\left[{ }^{35} \mathrm{~S}\right]$ methionine and electrophoretic analysis on SDS-polyacrylamide gels. Cell cultures were grown in M9glucose media supplemented with the appropriate antibiotics for plasmid-containing strains and all amino acids except methionine. Aliquots of mid-log phase cultures were labeled with $5-15 \mu \mathrm{Ci}$ of $\left[{ }^{35} \mathrm{~S}\right]$ methionine for $1 \mathrm{~min}$, chased with excess unlabeled methionine for $1 \mathrm{~min}$, and then precipitated on ice in $5 \%$ trichloroacetic acid (TCA). The precipitate was collected by centrifugation and washed well with $80 \%$ acetone before drying, resuspension in SDS-sample buffer, and analysis on SDS-polyacrylamide gels (Laemmli 1970).

The synthesis of GroEL, DnaK, or GalK was examined quantitatively by immunoprecipitation. Aliquots from cell cultures that had been pulse-labeled and pr:cipitated as described above were resuspended in $2 \%$ SDS and $50 \mathrm{~mm}$ Tris (pH 7.5). Samples were treated with antiserum to the individual proteins, essentially as described by Kessler (1981), using Staphylococcus aureus cells fixed with protein A as an immunoadsorbent. Polyclonal antisera raised against either GroEL, DnaK, or GalK were kindly supplied by R. Hendrix, C. Georgopoulos, and T. Warner, respectively. An equal amount of $\left[{ }^{3} \mathrm{H}\right]$ lysine-labeled cell extract was added to each sample prior to immunoprecipitation as a source of ${ }^{3} \mathrm{H}$-labeled GroEL, DnaK, or GalK, which provided a means to correct for losses during the analysis. Immunoprecipitates were examined by SDS-polyacrylamide gel electrophoresis and autoradiography. The bands corresponding to the individual proteins were cut out, solubilized, and analyzed by liquid scintillation counting. The synthesis rates of individual proteins are expressed as a fraction of total protein synthesis following correction for losses during the analysis, as described in Grossman et al. (1987).

\section{S1 mapping}

The level of mRNA from the groE operon, or from heat shock promoter fusions to galk, was determined essentially as described in Burton et al. (1983). RNA was prepared from expo- 
nentially growing cells by lysis with lysozyme and SDS, followed by extraction of RNA with water-saturated phenol at $64^{\circ} \mathrm{C}$. Total RNA $(5-20 \mu \mathrm{g})$ was hybridized to DNA probes $(0.2$ $\mu \mathrm{g}$ ) end-labeled with $\left[\gamma^{-32} \mathrm{P}\right] \mathrm{ATP}$ and polynucleotide kinase. The probes were prepared from restriction digests of plasmid clones of the groE operon or heat shock promoter fusions to galK. Hybridizations were carried out at $50^{\circ} \mathrm{C}$ for $10 \mathrm{hr}$ under the conditions of Berk and Sharp (1978). Hybrids were treated with 150 units of $\mathrm{S} 1$ nuclease at $37^{\circ} \mathrm{C}$ for $30 \mathrm{~min}$ and analyzed on $5 \%$ polyacrylamide $/ 50 \%$ (wt/vol) urea sequencing gels.

\section{$\sigma^{32}$ level}

The level of $\sigma^{32}$ was determined by Western blot analysis, as described previously (Straus et al. 1987). Total protein extracts were prepared by sampling aliquots of cell culture directly into TCA, collecting the precipitate by centrifugation, washing with $80 \%$ acetone, drying the pellet under vacuum and resuspending in SDS-sample buffer. Proteins were resolved on SDS-polyacrylamide gels, transferred to nitrocellulose, treated with antiserum against $\sigma^{32}$ and goat anti-rabbit antibody conjugated with alkaline phosphatase (CalBiochem), and then developed with 5bromo-4-chloro-3-indolyl phosphate and nitroblue tetrazolium. The developed blots were scanned by reflective densitometry. A mutant form of $\sigma^{32}$ with an altered mobility on SDS-polyacrylamide gels was included in the cell extracts as a standard to correct for differential losses during the analysis.

\section{dnaKJ $m R N A$ synthesis}

The synthesis of mRNA from the dnaKI operon was determined by labeling with $\left[{ }^{3} \mathrm{H}\right]$ uridine and hybridizing with ${ }^{3} \mathrm{H}$-labeled RNA to filter-bound $\lambda d n a K J$ DNA. Cultures were grown with MOPS-glucose supplemented with all amino acids and appropriate antibiotics, but without uracil. Aliquots of exponentially growing cultures were labeled for $1 \mathrm{~min}$ with $50 \mu \mathrm{Ci}$ / $\mathrm{ml}\left[{ }^{3} \mathrm{H}\right]$ uridine and then immediately incubated at $100^{\circ} \mathrm{C}$ for 2 $\min$ in $0.5 \%$ SDS, $50 \mathrm{~mm} \mathrm{NaCl}$, and $4 \mathrm{~mm}$ EDTA. RNA was extracted with water-saturated phenol at $64^{\circ} \mathrm{C}$, precipitated with isopropanol, dried under vacuum, and resuspended in hybridization buffer $[50 \%$ deionized formamide, $0.1 \mathrm{M}$ Tris $[\mathrm{pH}$ 7.5), $0.75 \mathrm{M} \mathrm{NaCl}, 0.5 \%$ SDS, $2 \mathrm{~mm}$ EDTA]. RNA was hybridized to $\sim 5 \mu \mathrm{g}$ of denatured $\lambda$ cI857 Sam7 DNA, or $\lambda$ cI857 dnaKJ DNA bound to 6 - $\mathrm{mm}$-diameter nitrocellulose filters. Hybrids were formed at $38^{\circ} \mathrm{C}$ for at least $8 \mathrm{hr}$ before treatment with $1 \mu \mathrm{g} / \mathrm{ml}$ RNase A, $1 \mathrm{U} / \mathrm{ml}$ RNase T1 (Boehringer-Mannheim) in $2 \times \mathrm{SSC}(0.3 \mathrm{M} \mathrm{NaCl}, 0.03 \mathrm{M}$ sodium citrate at $\mathrm{pH} 7)$ for $30 \mathrm{~min}$. After extensive washing in $2 \times \mathrm{SSC}$, the filters were dried and counted in scintillation fluid. Relative dnaKJ mRNA synthesis is the counts per minute bound to the $\lambda$ cI857 dnaKJ filter, minus the counts per minute bound to the $\lambda \mathrm{cI} 857$ Sam7 filter, expressed as a fraction of the total counts per minute in the hybridization.

\section{Acknowledgments}

We would like to thank T. Yura and N. Kusukawa for sharing unpublished data and Alan Grossman for comments on the manuscript. This work was supported by a grant from the $\mathrm{Na}$ tional Institutes of Health (R01 GM-36278).

\section{References}

Bahl, H., H. Echols, D. Straus, D. Court, R. Crowl, and C. Georgopoulos. 1987. Induction of a heat shock response of E. coli through stabilization of $\sigma^{32}$ by phage $\lambda$ cIII protein. Genes Dev. 1: 57-64.
Berk, A. and P. Sharp. 1978. Spliced early mRNAs of simian virus 40. Proc. Natl. Acad. Sci. 75: 1274-1278.

Bloom, M., S. Skelly, R. VanBogelen, F. Neidhardt, N. Brot, and H. Weissbach. 1986. In vitro effect of the Escherichia coli heat shock regulatory protein on expression of heat shock genes. I. Bacteriol. 166: 380-384.

Burton, Z., C. Gross, K. Watanabe, and R. Burgess. 1983. The operon that encodes the sigma subunit of RNA polymerase also encodes ribosomal protein S21 and DNA primase in $E$. coli K12. Cell 32: 335-349.

Cowing, D.W., J.C.A. Bardwell, E.A. Craig, C. Woolford, R.W. Hendrix, and C. Gross. 1985. Consensus sequence for Escherichia coli heat-shock gene promoters. Proc. Natl. Acad. Sci. 80: $2679-2683$.

Dodson, M., R. McMacken, and H. Echols. 1989. Specialized nucleoprotein structures at the origin of replication of bacteriophage $\lambda$. J. Biol. Chem. 264: 10719-10725.

Fujita, N., T. Nomura, and A. Ishihama. 1987. Promoter selectivity of Escherichia coli RNA polymerase. $\%$. Biol. Chem. 262: $1855-1859$.

Goloubinoff, P., A. Gatenby, and G. Lorimer. 1989. GroE heatshock proteins promote assembly of foreign prokaryotic ribulose bisphosphate carboxylase oligomers in Escherichia coli. Nature 337: 44-47.

Gross, C., F. Engbaek, T. Flammang, and R. Burgess. 1976. Rapid micromethod for the purification of Escherichia coli ribonucleic acid polymerase and the preparation of bacterial extracts active in ribonucleic acid synthesis. I. Bacteriol. 128: $382-389$.

Gross, C., A. Grossman, H. Liebke, W. Walter, and R. Burgess. 1984. Effects of the mutant sigma allele rpoD 800 on the synthesis of specific macromolecular components of the Escherichia coli K12 cell. I. Mol. Biol. 172: 283-300.

Grossman, A.D., J.W. Erickson, and C.A. Gross. 1984. The $h t p R$ gene product of $E$. coli is a sigma factor for heat-shock promoters. Cell 38: 383-390.

Grossman, A.D., D.B. Straus, W.A. Walter, and C.A. Gross. 1987. $\sigma^{32}$ synthesis can regulate the synthesis of heat shock proteins in Escherichia coli. Genes Dev. 1: 179-184.

Herendeen, S.L., R.A. VanBogelen, and F.C. Neidhardt. 1979. Levels of major proteins of Escherichia coli during growth at different temperatures. I. Bacteriol. 139: 185-194.

Kessler, S.W. 1981. Use of protein A-bearing Staphylococci for the immunoprecipitation and isolation of antigens from cells. Methods Enzymol. 73: 31.

Laemmli, U.K. 1970. Cleavage of structural proteins during the assembly of the heat of bacteriophage T4. Nature 227: 680685.

Lemaux, P.G., S.L. Herendeen, P.L. Boch, and F.C. Neidhardt. 1978. Transient rates of synthesis of individual polypeptides in E. coli following temperature shifts. Cell 13: 427-434.

Lesley, S., N. Thompson, and R. Burgess. 1987. Studies of the role of the Escherichia coli heat shock regulatory proteins $\sigma^{32}$ by the use of monoclonal antibodies. I. Biol. Chem. 262: 5404-5407.

Liberek, K., C. Georgopoulos, and M. Zylicz. 1988. Role of the Escherichia coli DnaK and DnaJ heat shock proteins in the initiation of bacteriophage $\lambda$ DNA replication. Proc. Natl. Acad. Sci. 85: 6632-6636.

McKenney, K., H. Shimatake, D. Court, U. Schmeissner, and M. Rosenberg. 1981. A system to study promoter and terminator signals recognized by $E$. coli RNA polymerase. In Gene amplification and analysis 2 (ed. J. Chirikjian and T. Papas), pp. 383-415. North Holland Press, Amsterdam.

Neidhardt, F.C. and R.A. VanBogelen. 1981. Positive regulatory gene for temperature-controlled proteins in Escherichia coli. Biochem. Biophys. Res. Commun. 100: 894-900. 
Straus et al.

1987. Heat shock response. In Escherichia coli and Salmonella typhimurium: Cellular and molecular biology led. F.C. Neidhardt, J.C. Ingraham, K.B. Low, B. Magasanik, M. Schaecter, and H.E. Umbarger\}, pp. 1334-1345. American Society for Microbiology, Washington, D.C.

Paek, K.H. and G.C. Walker. 1986. Defect in expression of heat-shock proteins at high temperature in $x$ thA mutants. J. Bacteriol. 165: 763-770.

Skelly, S., T. Coleman, C.F. Fu, N. Brot, and H. Weissbach. 1987. Correlation between the 32-kDa $\sigma$ factor levels and in vitro expression of Escherichia coli heat shock genes. Proc. Natl. Acad. Sci. 84: 8365-8369.

Straus, D.B., W.A. Walter, and C.A. Gross. 1987. The heat shock response of $E$. coli is regulated by changes in the concentration of $\sigma^{32}$. Nature 329: 348-351.

Tauro, T., N. Kusukawa, T. Yura, and K. Ito. 1989. Transient shut off of Escherichia coli heat shock protein synthesis upon temperature shift down. Biochem. Biophys. Res. Commun. 163: 438-443.

Yamamori, T. and T. Yura. 1982. Genetic control of heat-shock protein synthesis and its bearing on growth and thermal resistance in Escherichia coli K12. Proc. Natl. Acad. Sci. 79: $860-864$.

Zhou, Y.-N., N. Kusukawa, J.W. Erickson, C.A. Gross, and T. Yura. 1988. Isolation and characterization of Escherichia coli mutants that lack the heat shock sigma factor $\sigma^{32}$. $I$. Bacteriol. 170: 3640-3649. 


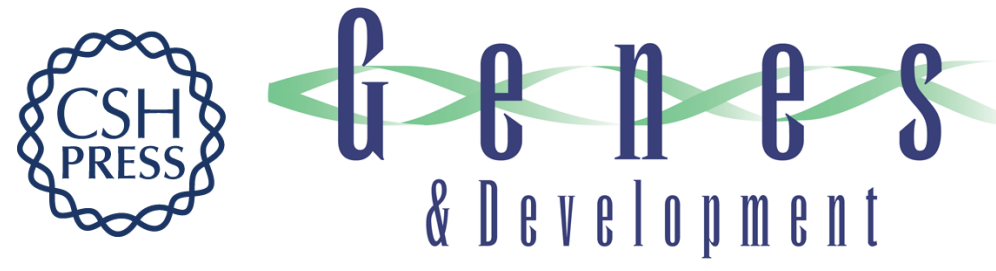

\section{The activity of sigma 32 is reduced under conditions of excess heat shock protein production in Escherichia coli.}

D B Straus, W A Walter and C A Gross

Genes Dev. 1989, 3:

Access the most recent version at doi:10.1101/gad.3.12a.2003

References This article cites 25 articles, 14 of which can be accessed free at:

http://genesdev.cshlp.org/content/3/12a/2003.full.html\#ref-list-1

License

Email Alerting

Service

Receive free email alerts when new articles cite this article - sign up in the box at the top right corner of the article or click here.

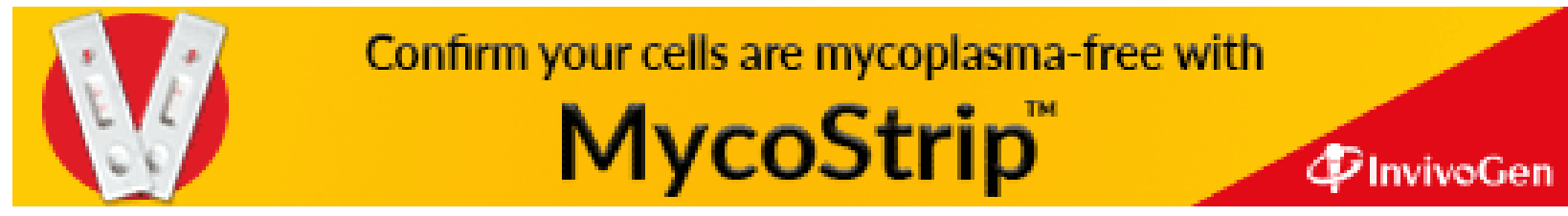

